\title{
Editorial
}

\section{BORIMIR TOTEV}

Executive Editor of SLOVO, 2016-2017

With nearly three decades of history behind us, and one volume short of thirty, SLOVO closes in on another successful year. We continue to deliver on our promise to maintain a fresh view on the interdisciplinary regional affairs of Russia, East \& Central Europe and Eurasia. In view of the recent raptures surrounding the futures of the Central European University in Budapest and the European University at St. Petersburg, I dedicate this issue to our friends and colleagues at those institutions, which continue the daily fight for academic freedom and dignity.

This issue opens with Nadège Mariotti's study into the evolution and processes of instrumentalisation of the memory of A. G. Stakhanov's record mining achievements, through the unraveling of Gaumont Pathé's rich archives. Following from this, Andreea Mironescu takes us on a journey of remembering the Armenian Genocide with Varujan Vosganian's 'The Book of Whispers', correlating with the upcoming publishing of the book's English translation. In the final article of this issue, Türkan Olcay shares the enticing story of the life and work of the first Russian female orientalist, Madame Gülnar, with a visual supplement for the enjoyment of our readers. We have also included the translations of two flash fiction stories by Irina Luk'ianova as provided by Genevieve Silk and Cüshla Silk. The issue concludes with a book review of 'The New Russian Nationalism: Imperialism, Ethnicity and Authoritarianism 2000-2015' by Rachael Horwitz.

The issue was made possible thanks to the precious amount of hours invested by the journal's Board of Editors: Lenka Murarikova, Eleanor Rees, Alexandra Bulat, Eliot Rothwell, Catriona McDermid, Emma Anne Hatto, and Book Reviews Editor, Josefin Book Jönsson. I must also acknowledge the role of all the academic referees who continuously assist with the maintenance of SLOVO's high standards and, of course, extend my thanks to you - our dear readers - for your enduring support and interest in our publication. 